\title{
Are some teat disinfectant formulations more effective against specific bacteria isolated on teat skin than others?
}

Sarah Rose Fitzpatrick ${ }^{1,2}$, Mary Garvey², Jim Flynn ${ }^{1}$, Kieran Jordan $^{3}$ and David Gleeson ${ }^{\text {** }}$

\begin{abstract}
The use of pre- and post-milking teat disinfectants can reduce teat bacterial load and aid in the collection of highquality milk. The objective of this study was to compare the reduction in bacteria populations on teat skin after the application of different commercial teat disinfectant products. Ten teat disinfectant products were applied to the teats of 10 Holstein-Friesian cows. One cow received one teat disinfectant product at each sampling point before cluster application for milking. A composite swab sample was taken of the 4 teats of each cow before and after teat disinfectant application. Swab samples were placed on three different selective agars to enumerate bacterial counts of staphylococcal, streptococcal and coliforms isolates on teat skin. Staphylococcal isolates were the most prominent bacterial group recovered on teat swabs (49\%), followed by streptococcal (36\%) and coliform (15\%) isolates before the application of disinfectant. The average bacterial reductions on teat skin were shown to be $76 \%, 73 \%$ and $60 \%$ for staphylococcal, streptococcal and coliform isolates, respectively. All of the teat disinfectant products tested reduced teat bacterial load for all three bacterial groups. Product 4 containing $0.6 \% \mathrm{w} / \mathrm{w}$ diamine was the most effective against bacterial populations of staphylococcal and streptococcal isolates on teat skin with a reduction of $90 \%$ and $94 \%$, respectively. Whereas product 10 , which contained $0.5 \% \mathrm{w} / \mathrm{w}$ iodine, resulted in the highest reduction in coliforms on teat skin with a reduction of $91 \%$. Results from this study suggest that specific bacterial population loads on teats can be reduced using different teat disinfectant formulations.
\end{abstract}

Keywords: Dairy cows, Dairy hygiene, Swabs, Teat bacterial load, Teat disinfection

\section{Findings}

The teat orifice is the first line of defence from the invasion of mastitis pathogens into the teat canal and mammary glands. High bacterial contamination may increase the chances of more bacteria entering the teat orifice and causing infection [1]. The removal of bacteria pre- and post-milking can lower the occurrence of new intramammary infections (IMI's) [2, 3]. Therefore, determining the efficacy of teat disinfectant products against bacteria naturally present on teat skin is important. Teat swabbing has been used to determine the effect of pre-milking teat preparation treatments $[1,2,4-6]$, enumerate

\footnotetext{
*Correspondence: david.gleeson@teagasc.ie

${ }^{1}$ Teagasc, Animal \& Grassland Research and Innovation Centre,

Moorepark, Fermoy, County Cork, Ireland

Full list of author information is available at the end of the article
}

and identify bacteria present on teat skin surface [7-11]. Previous studies focused on evaluating pre-milking teat cleaning procedures. Whereas, this study will determine the impact of 10 pre- and post-milking teat disinfectant products, with different ingredients of varying concentration, on the reduction of teat skin bacterial load.

This study was approved by the Teagasc Animal Ethics Committee (ref. TAEC168-2017). The BS EN 1656 is a European standard which is used to test chemical disinfectants used in the veterinary area against bacteria recommended by the standard. To meet the requirements of this standard for teat disinfectants, the product must demonstrate at least a $10^{5}$ log reduction $(99.999 \%$ reduction) within 5 min against Staphylococcus aureus (ATCC ${ }^{\circledR} 6538^{\mathrm{TM}}$ ), Streptococcus uberis (ATCC ${ }^{\circledR} 19436^{\mathrm{TM}}$ ) and Escherichia coli $\left(\mathrm{ATCC}^{\circledR} 10536^{\mathrm{TM}}\right.$ ). Before the disinfectant products were applied to cow's teats, each product was

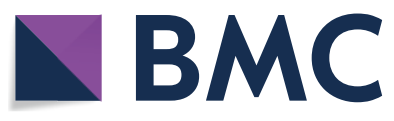

(c) The Author(s) 2019. This article is distributed under the terms of the Creative Commons Attribution 4.0 International License (http://creativecommons.org/licenses/by/4.0/), which permits unrestricted use, distribution, and reproduction in any medium, provided you give appropriate credit to the original author(s) and the source, provide a link to the Creative Commons license, and indicate if changes were made. The Creative Commons Public Domain Dedication waiver (http://creativecommons.org/ publicdomain/zero/1.0/) applies to the data made available in this article, unless otherwise stated. 
tested using the BS EN 1656. Ten disinfectant products (Table 1) were applied to the teats of 10 Holstein-Friesian cows. All teat disinfectant products were ready-touse (RTU) while one product (product 7) was mixed with an activator before use, according to manufacturer's recommendations, and was considered a RTU product by the manufacturer. The disinfectant products were suitable for both pre- and post-milking teat disinfection, with the exception of products 7 and 10, which were recommended for use only for post-milking disinfection. The cows were housed, in one group, indoors, on matted cubicle beds dressed with ground limestone daily to maintain a dry bed.

Before sampling, swabs were moistened [4] in sterile trypticase soy broth (TSB) (Merck Millipore, Ireland) to aid in the collection of bacteria from the teat skin before and after teat disinfectant application. Over 10 milkings (AM and PM; 5 days), teat disinfectant products were applied to the teats of 10 cows ( 10 replicates per product). Every cow received each product once over the duration of the trial, with a different product applied at each milking. Before (PRE) the application of a test teat disinfectant, a composite teat skin swab was collected from all 4 teats. For PRE swab samples, swabs were drawn across the teat orifice and down the side of each teat avoiding contact with the udder hair and cows flank [2, 10]. All teats of the cow were then immersed in a test teat disinfectant using a teat dip cup. The teat disinfectant was then left on the teat skin for up to $1 \mathrm{~min}$. Next, teats were dry wiped with a single-use paper towel. A pilot study, where the inclusion of a dry wipe was compared to no dry wipe after application of teat disinfectant products, showed that there was no difference in the reduction of bacterial load on teat skin. Following this, composite swab samples were collected (POST) from all 4 teats in a similar manner to that for the PRE samples. However,
POST samples were collected on the opposite side of the teats. Immediately after sampling, swabs were placed into individual sterile bottles containing $10 \mathrm{~mL}$ of sterile TSB and neutraliser $(30 \mathrm{~g} / \mathrm{L}$ polysorbate 80 and $3 \mathrm{~g} / \mathrm{L} \mathrm{L-} \alpha-$ phosphatidylcholine from egg yolk) and placed in storage at $-20^{\circ} \mathrm{C}$ [10], within $1 \mathrm{~h}$ of sampling, for 7-14 days before undergoing laboratory analysis. A previous study demonstrated that storage of skin swab samples at different temperatures did not affect the abundance or diversity of bacterial population [12]. A total of 200 teat swab samples were collected during the trial. For the bacterial counts, maximum recovery diluent was used to make 1:100 dilutions in sterile tubes for the PRE samples. The POST sample was used undiluted. The samples were subsequently plated, in triplicate, onto 3 separate agars; Baird parker agar (Merck Millipore, Ireland) for staphylococcal isolates, modified Edwards agar (Sigma-Aldrich, Ireland) with $5 \%$ sterile blood for streptococcal isolates and MacConkey agar (Merck Millipore, Ireland) for coliform isolates [1]. Following incubation at $37^{\circ} \mathrm{C}$ for $24 \mathrm{~h}$, microbial counts for each bacterial group were manually counted. Bacterial species within each isolate group were not defined.

Bacterial counts $(\mathrm{cfu} / \mathrm{mL})$ were transformed to base10 logarithm for analysis. Statistical analysis was performed using SAS version 9.4 [13]. Reduction in bacteria of teat skin was calculated as the difference between the $\log _{10}$ values of PRE and POST. PROC GLIMMIX was used to perform multiple pair-wise comparisons. The LSMEANS statement in PROC GLIMMIX was used to differentiate statistical differences. Residual checks were made to ensure assumptions of analysis were met. The reductions for the bacterial isolate groups tested were analysed using 3 models (one for each bacterial group). This model included the reduction as a dependent variable and product, day and time as

\section{Table 1 Test teat disinfectant product code and active ingredient, as declared by the manufacturer on product label}

\begin{tabular}{|c|c|c|c|}
\hline Code & Product & Ingredient & Manufacturer/supplier \\
\hline 1 & Lacto-cel $^{\mathrm{a}}$ & $2.4 \% \mathrm{w} / \mathrm{w}$ lactic acid & Biocel Ltd. \\
\hline 2 & Duogold ${ }^{a}$ & $2 \% \mathrm{w} / \mathrm{w}$ lactic acid and $0.3 \% \mathrm{w} / \mathrm{w}$ chlorhexidine gluconate & Gold Assure \\
\hline 3 & Arkshield $^{\mathrm{a}}$ & $5 \% \mathrm{w} / \mathrm{w}$ lactic acid and $0.3 \% \mathrm{w} / \mathrm{w}$ chlorhexidine & Ark Farm Innovations Ltd. \\
\hline 4 & Super cow teat foam ${ }^{a}$ & $0.6 \% \mathrm{w} / \mathrm{w}$ diamine & Milk Solutions Ltd. \\
\hline 5 & Sensodip $50^{\mathrm{a}}$ & $0.5 \%$ w/w chlorhexidine & GEA Farm Technologies Ltd. \\
\hline 6 & PureChem chlorhexidine ${ }^{a}$ & $0.29 \%$ w/w chlorhexidine & Central Chemical Supplies Ltd. \\
\hline 7 & Kenomix ${ }^{b}$ & $0.0157 \%$ w/w chlorine dioxide & CID Lines N.V. \\
\hline 8 & Lanodip pre-post ${ }^{\mathrm{a}}$ & $0.29 \% \mathrm{w} / \mathrm{w}$ iodine and $0.8 \% \mathrm{w} / \mathrm{w}$ lactic acid & Kilco International Ltd. \\
\hline 9 & Hypred quick spray ${ }^{\text {a }}$ & $2 \% \mathrm{w} / \mathrm{w}$ lactic and $0.1 \% \mathrm{w} / \mathrm{w}$ salicylic acid & Grassland Agro Ltd. \\
\hline 10 & Maxidine RTU ${ }^{b}$ & $0.5 \% \mathrm{w} / \mathrm{w}$ iodine & Biocel Ltd. \\
\hline
\end{tabular}

\footnotetext{
a Pre- and post-milking application
}

b Post-milking application only 
independent variables. The equation for all models was; Reduction $=$ Product + Day + Time + Day $\times$ Product + Time $\times$ Product, where reduction was the base-10 logarithm of the $\mathrm{cfu} / \mathrm{mL}$ unit of interest +1 , product was the products tested, day was the date of sampling and time refers to the milking the swab was collected (AM or PM). The cow was the experimental unit.

In this study, all 10 disinfectant products were tested using the BS EN 1656 protocol. All products achieved a $\log$ reduction ranging from 5.31 to 5.96 within 5 min of treatment time for the 3 recommended bacteria. Therefore, indicating that the disinfectant products provide sufficient levels of inactivation and meet the requirements of the BS EN 1656.

Overall, day had a significant effect on the bacterial numbers on teats within the study but there was no day by product effect for all three bacterial groups $(\mathrm{P}>0.05)$. Furthermore, the time of collection (AM or PM milking) had no significant effect on the reduction of bacterial numbers $(P>0.09)$, but bacterial counts were higher for all swabs collected in the AM milking in comparison to swabs collected in the PM milking. The difference between bacterial counts for time of sampling may be due to the different time intervals between milkings (i.e. $7 \mathrm{~h}$ between AM and PM milking and $17 \mathrm{~h}$ between PM and AM milking). In natural exposure studies, day and time of collection may impact bacterial load on teat skin due to factors such as; management and environment, which can cause a fluctuation of bacterial load on skin surface $[4,5,14,15]$.

Staphylococcal isolates were the most prominent bacterial group recovered on teat swabs (49\%), followed by streptococcal (36\%) and coliform (15\%) isolates. This was similar to previous studies where staphylococcal species were more abundant than streptococcal species $[1,2]$. All teat disinfectant products used in the study reduced bacterial load on teat skin. The overall reduction in bacterial counts was significant $(\mathrm{P}<0.05)$ across all treatments for staphylococcal, streptococcal and coliform isolates (Fig. 1). These results agree with previous studies which showed that teat disinfection reduced bacterial load on teat skin $[1,2,5]$, but the reduction of bacterial load was slightly lower in this study in comparison to other studies $[1,4]$.

The results for each bacterial isolate group can be observed in Table 2. For staphylococcal isolates, average bacterial reduction on teat skin was $76 \%$, (range; $56 \%$ - 90\%). Products containing 0.6\% diamine (product 4) and $0.5 \%$ chlorhexidine (product 5) were the most effective in reducing the bacterial load on teat skin, with both products giving a bacterial reduction of $90 \%$. The average bacterial reduction on teat skin for streptococcal isolates was $73 \%$ (range: 59\%-93\%). A product

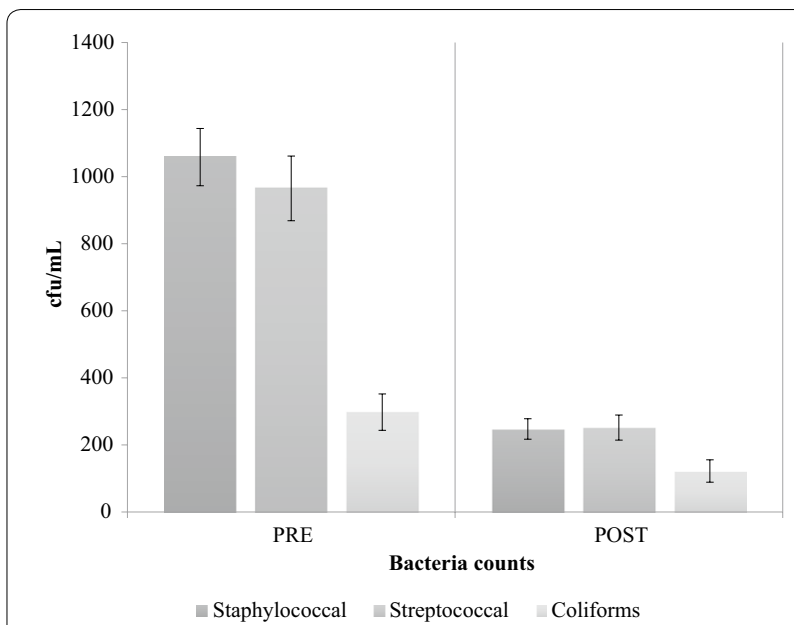

Fig. 1 Overall means for staphylococcal, streptococcal and coliform isolate counts (cfu/mL) on teat swab samples before (PRE) and after (POST) the application of test teat disinfectant products. Error bars indicate SEM

containing $0.6 \%$ diamine (product 4 ) was the most effective in reducing the bacterial load on teat skin, achieving a reduction of $94 \%$. Coliform bacterial load on teat skin was reduced, on average, by $60 \%$ (range: $20 \%-88 \%$ ). A product containing $0.5 \% \mathrm{w} / \mathrm{w}$ iodine (product 10) was the most effective and achieved a reduction of $91 \%$. This agrees with other studies where iodine has been shown to be effective against a wide range of staphylococcal $[2,5,16]$ streptococcal and coliform species $[1,2,5,6]$.

A limitation of the study was the lower log reduction obtained using teat swabbing in comparison to the laboratory method, BS EN 1656. This may have been influenced by the low initial level of bacterial isolates present on teat skin prior to the application of disinfectant products. Challenging the teat skin surface with a known concentration of a specific bacterial strain, rather than depending on the natural bacteria present, may help to ensure initial levels of bacteria on teat skin to reflect log reductions required in the BS EN 1656. Furthermore, the time period in which the teat disinfectant products were left on the teat skin $(1 \mathrm{~min})$ may not have been long enough to make a comparison with the BS EN 1656 as this protocol requires a treatment time of $5 \mathrm{~min}$. In addition, when swabbing the teat before and after teat disinfection, it was considered important to include the teat orifice in both sample collections as microbial colonisation of the teat canal and orifice can serve as a reservoir for the development of new IMIs during lactation [17].

In conclusion, all teat disinfectant products used in this study can reduce the bacterial load on teat skin of dairy cows. Additionally, a variation in sensitivity and 


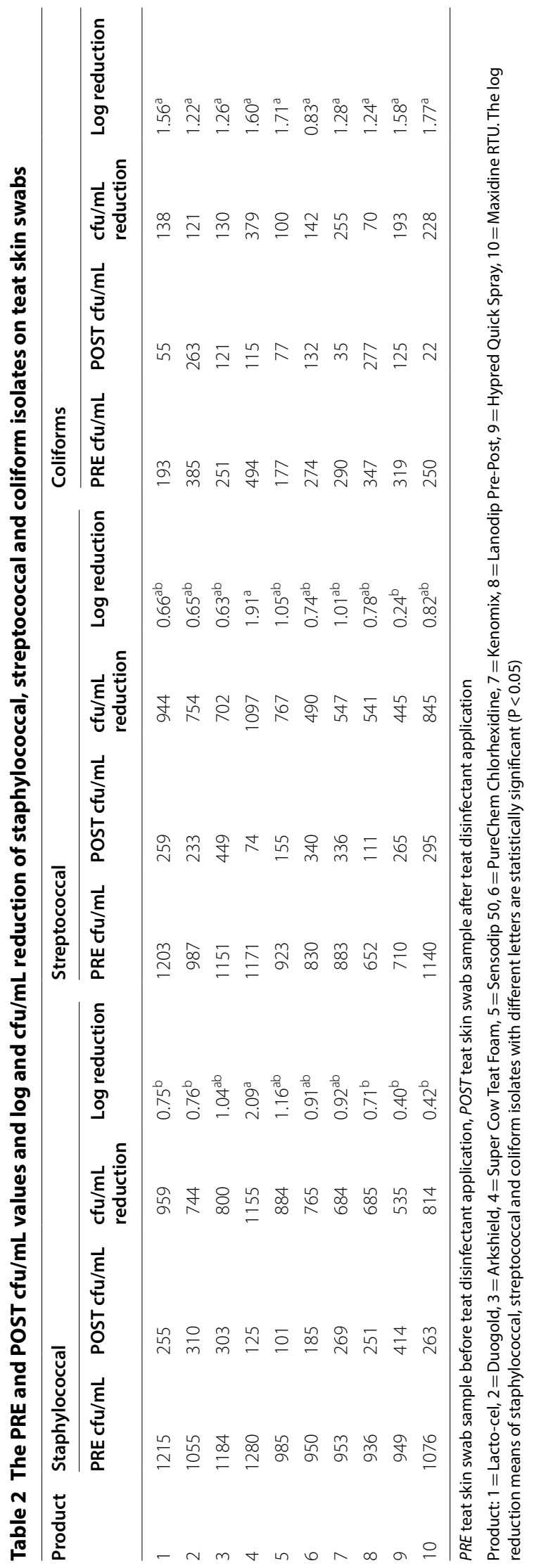


resistance to active ingredients was observed across the bacteria isolates tested. Furthermore, longer natural exposure trials should be undertaken to evaluate the efficacy of the test teat disinfectants ability to reduce new IMIs.

\section{Abbreviations}

IMI: intramammary infection; POST: swab sample collected 1 min after teat disinfection; PRE: swab sample collected before teat disinfection; SEM: standard error mean; TSB: tryptic soy broth.

\section{Authors' contributions}

SF and DG designed and supervised the study. DG and SF carried out swab sample collection. SF undertook all of the sample analysis under the supervision of JF. SF wrote the manuscript. DG, MG, JF and KJ contributed to the editing of this manuscript. All authors read and approved the final manuscript.

\section{Author details}

${ }^{1}$ Teagasc, Animal \& Grassland Research and Innovation Centre, Moorepark, Fermoy, County Cork, Ireland. ${ }^{2}$ Cellular Health and Toxicology Research Group, Institute of Technology Sligo, County Sligo, Ireland. ${ }^{3}$ Teagasc Food Research Centre, Moorepark, Fermoy, County Cork, Ireland.

\section{Acknowledgements}

The authors wish to acknowledge the companies who kindly provided their products for testing and JohnPaul Murphy and farm staff at the Animal and Grassland Research and Innovation Centre Dairy Unit, Teagasc, Moorepark, Fermoy, County Cork, Ireland.

\section{Competing interests}

The authors declare that they have no competing interests.

\section{Availability of data and materials}

The datasets used and/or analysed during the current study are available from the corresponding author on reasonable request.

\section{Consent for publication}

Not applicable.

\section{Ethics approval and consent to participate}

This study was undertaken with license under the Cruelty to Animals Act, 1876. This study has also been approved by the Teagasc Animal Ethics Committee (ref. TAEC168-2017). The animals were handled according to high ethical standards and national legislation.

\section{Funding}

Authors gratefully acknowledge funding from the Dairy Research Levy Fund administered by Dairy Research Ireland. Sarah Fitzpatrick is in receipt of a Teagasc Walsh Fellowship (Ref: 2016054).

\section{Prior publication}

Data has not been published previously.

\section{Publisher's Note}

Springer Nature remains neutral with regard to jurisdictional claims in published maps and institutional affiliations.

Received: 23 January 2019 Accepted: 16 April 2019

Published online: 25 April 2019

\section{References}

1. Baumberger C, Guarin JF, Ruegg PL. Effect of 2 different premilking teat sanitation routines on reduction of bacterial counts on teat skin of cows on commercial dairy farms. J Dairy Sci. 2016;99:2915-29.

2. Gleeson D, Flynn J, O'Brien B. Effect of pre-milking teat disinfection on new mastitis infection rates of dairy cows. Irish Vet J. 2018;71:1-8.

3. Pankey JW. Pre-milking udder hygiene. J Dairy Sci. 1989;72:1308-12.

4. Gibson H, Sinclair LA, Brizuela CM, Worton HL, Protheroe RG. Effectiveness of selected premilking teat-cleaning regimes in reducing teat microbial load on commercial dairy farms. Lett Appl Microbiol. 2008;46:295-300.

5. Gleeson D, O'Brien B, Flynn J, O'Callaghan E, Galli F. Effect of pre-milking teat preparation procedures on the microbial count on teats prior to cluster application. Irish Vet J. 2009;62:461.

6. Mišeikienè R, Rudejevienè J, Gerulis G. Effect of pre-milking antiseptic treatment on the bacterial contamination of cow teats'skin. Bulgarian J Vet Med. 2015;18:159-66.

7. Vijaya Kumar A, Venkateswara Rao L, Kishan Kumar M, Srinu B, Madhava Rao T. Efficacy of udder disinfectants on reduction of bacterial load and certain pathogens of public health significance. J Microbiol Biotech Res. 2012:2:147-51.

8. Monsallier F, Verdier-Metz I, Agabriel C, Martin B, Montel MC. Variability of microbial teat skin flora in relation to farming practices and individual dairy cow characteristics. Dairy Sci Technol. 2012;92:265-78.

9. Guarin JF, Baumberger C, Ruegg PL. Anatomical characteristics of teats and premilking bacterial counts of teat skin swabs of primiparous cows exposed to different types of bedding. J Dairy Sci. 2017;100:1436-44.

10. Rowbotham RF, Ruegg PL. Bacterial counts on teat skin and in new sand, recycled sand, and recycled manure solids used as bedding in freestalls. J Dairy Sci. 2016;99:6594-608.

11. Adkins PRF, Dufour S, Spain JN, Calcutt MJ, Reilly TJ, Stewart GC, et al. Cross-sectional study to identify staphylococcal species isolated from teat and inguinal skin of different-aged dairy heifers. JDairy Sci. 2018;101:3213-25.

12. Lauber CL, Zhou N, Gordon Jl, Knight R, Fierer N. Effect of storage conditions on the assessment of bacterial community structure in soil and human-associated samples. FEMS Microbiol Lett. 2010;307:80-6.

13. SAS Institute Inc. Sas/Stat ${ }^{\circledR} 9.4$ User's guide. 2 nd ed. Cary: SAS Institute Inc; 2014

14. Paduch $\mathrm{JH}$, Kromker V. Colonization of the teat skin and the teat canal of lactating dairy cattle by mastitis pathogens. Vet Pract Issue G Large Ani Farm Anim. 2011;39:71-6.

15. Paduch J-H, Mohr E, Krömker V. The association between teat end hyperkeratosis and teat canal microbial load in lactating dairy cattle. Vet Microbiol. 2012;158:353-9.

16. Enger BD, Fox LK, Gay JM, Johnson KA. Reduction of teat skin mastitis pathogen loads: differences between strains, dips and contact times. J Dairy Sci. 2015;98:1354-61.

17. Verdier-Metz I, Gagne G, Bornes S, Monsallier F, Veisseire P, Delbès-Paus C, et al. Cow teat skin, a potential source of diverse microbial populations for cheese production. Appl Environ Microbiol. 2012;78:326-33.

Ready to submit your research? Choose BMC and benefit from:

- fast, convenient online submission

- thorough peer review by experienced researchers in your field

- rapid publication on acceptance

- support for research data, including large and complex data types

- gold Open Access which fosters wider collaboration and increased citations

- maximum visibility for your research: over $100 \mathrm{M}$ website views per year

At $\mathrm{BMC}$, research is always in progress.

Learn more biomedcentral.com/submissions 